\title{
Informally Established Relations Between the Superior and the Subordinate: Turkey's Example
}

\author{
Sinan Çaya ${ }^{a}$
}

\begin{abstract}
Turkish people display deep consideration for the concept of hierarchy. Historically, they had been always calculating and measuring the relative positions of authority symbols with respect to one another; because they had their own dealings with those who held political power. Should they render their young sons to the service of the feudal lords or the state? Should they consent to the say of the local forces or that of the central state power, when it comes to fixing the amounts and/or the kinds of taxes? Sometimes, the ordinary subjects of the Ottoman state were even openly torn apart in dilemmas whereby local powers were revolting against the central government of the Sultan placed at the capitol. Even the anoymous folk tales, which reflect people's opinions and mentalities in a manner very close to the truth, involve comparisons among the levels of power represented by certain officials/figures. When confronted with authority, the usual feeling contains a tint of respect, even though it is mainly a kind of resignition mixed with acceptance, leading to obedience in the end. A true, internalized respect itself is solely that which is directed toward the elderly people of the society. On the other hand, traditionally and conventionally, old age was closely associated with official or informal power and authority, anyhow. However, nowadays, in a very confusing manner, this former social understanding is undergoing rather fast changes with the advent of younger contemporary political figures.
\end{abstract}

\section{Keywords}

Turkey, hierarchy, society, informal (ways)

In Turkish society, hierarchy has its deep historical roots and everbody is thoroghly conscious of it.

As journalist Livaneli (December 30, 1998) said: "The tradition of hierarchy is embedded in the bones and flesh of the Turkish nation... The people, throughout the centuries, have observed and calculated issues like who is superior to whom or who can make whom obey an order".

He quoted a folk ballad (türkü), where the theme is very consistent and meaningful. As the actor of the offence gets bigger, the authority-figure in charge to handle the complaint, proportionately gets bigger:
Go tell the sparrow/Not to perch on our garden!/If it perches on our garden/Then I go report it to the watchman! Go tell the crow/Not to perch on our field!/If it perches on our field/Then I go report it to the village-chief! Go tell the stork/Not to perch on our farm!/If it perches on our farm/Then I go report it to the governor!

\footnotetext{
astanbul University, Turkey

Correspondent Author:

Sinan Çaya, Instructor of Social Graduate Elective Courses at Istanbul University, Institute of Marine Administration and Sciences, Istanbul, Turkey

E-mail: sinan.caya@gmail.com
} 


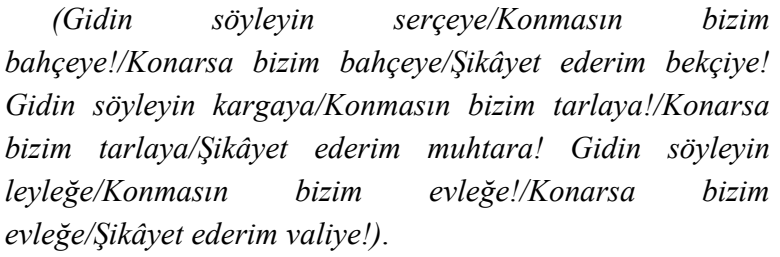

\section{OBEDIENCE IMPOSED AS A MUST}

In any hierarchial institution, recognition of higher authority is formally enforced. Moreover, it is informally encouraged within the organizational climate so that submission is not a demeaning attitude. The best example is in the military, where even harassment of the subordinate contributes to the formation of an ésprit de corps through somewhat peculiar social dynamics.

A scholar, Dornbusch, himself has experienced it in the United States Coast Guard Academy (where an upper classman often ordered him his room cleaned as a punishment, and then settled down for an uninterrupted chat with him). Here is what he says:

The basis for interclass solidarity... occurs through informal contacts between the upper classmen and swabs (freshman cadets)... The men who haze the swab... are (later) ashamed of their behavior. They are eager to convince the swab that they are good fellows. They visit his room to explain ${ }^{1}$ why they are being so harsh this week or to tell of a mistake he is making. Close friendships sometimes arise through such behavior. Such informal contacts serve to unite the classes and spread a "we-feeling" throughout the academy. In addition, the knowledge of common interests and a common destiny serves as a unifying force that binds together all academy graduates. (Dornbusch 1956: 101-102)

Aziz Nesin, as a former military highschool cadet, writes about this theme in his famous humorous style. In spite of his sarcastic expressions, a lot of truth lies in what he says.

I came to understand that he who would shout at me, he who had an official right to shout at me, represented the state. Anybody who could scold me was the state/the government (incarnate)... After completing my schooling and becoming an officer, I, too, would become the state (incarnate). My superior could do to me everything he wished. I, in turn, could do to those lower than me, everything I wished. But they used to teach us also this: The upper never does anything bad to the lower, never should do. Whatever he does is for our good. If we perceive his doings as being bad, that is because we do not understand the goodness there. For instance, our superior beats us, swears at us; but those are for our good, for our upbringing. (Nesin 1996a)

The author also mentions about the horse-playing kind of jokes popular among cadets.

It is the first night of the new cadet (kaydıkabûl) at school. The time is 2:00 a.m. Two former cadets wake the boy! (They bring the new cadet to the so-called "toilet-duty". He will supposedly replace the previous sentry, a collaborater of the joke). "The previous sentry" stands to attention and reports (tekmil verir): "Cadet number... from the ninth grade and the 10th Section! I was on duty in the toilets from 1:00 to 2:00 a.m. No events occured! Here there are 20 restrooms. Two of the taps are clogged and three other are leaking water! (Nesin 1996b)

\section{A TRADITIONAL OBSEQUIOUS ATTITUDE BEFORE ANYTHING OFFICIAL}

It will not be wrong to judge that usually the actual attitude toward people holding the legitimate power, is, more of a fear-type-of feeling, rather than internalized respect. Here at this point, too, the collective memory has a lot of "stuff" in reserve.

In the days of the Ottoman Empire, the power of the central government was felt only when taxes were not paid or some gesture of disrespect (such as refusal to go into the army at the proper time) was made toward the Sultan. Because of the absolute power of the Sultanate, villagers were usually careful not to offend the government. (Pierce 1964: 84)

In many folk tales, it can be seen that the figures of authority do not really deserve respect, but, they have the capability to hurt plain people.

The Vizier provokes this man against that man or even one man against his own children. He does not 
refrain from resorting to tricks in order to achieve success. He spends a lot of money in order to win the favor of the Sultan. He even admits to his own daughter's being sold like a slave, by the Sultan. Still, he is not genuinely loyal to the Sultan. On occasion he seduces the Sultan's wife when she has been confined to his protection. When the Sultan falls from the throne and impoverishes, then the Vizier totally abandons him. The Vizier gets involved in conspiracies aiming to assassinate the Sultan. Briefly, the Vizier is the strongest negative character in folk tales. In three tales and five funny anecdotes, bad roles are ascribed to the judge. This is the former (Ottoman) judge " $k a d l$ " figure. He is married but he indulges in debauchery. He tries to do injustice to needy people. He abuses his influence and his official position to this end. He proclaims unfair sentences in return for bribes. But he can not always get away with what he does: (A fictitious folk hero) Keloğlan (the bald boy), a dealer of old goods (eskici) and sometimes the Sultan penalizes him (Tuğrul 1969: 48-49).

\section{INTERNALIZATION OF BOWING ONE'S HEAD IN FRONT OF A COERCIVE FORCE}

Nevertheless, sometimes the deference for authority is internalized as it is seen in the relations between a civilian and a military figure:

\section{Case History}

In 1993, a funeral ceremony was held in a village of Çankırı, for a fallen soldier. The body of the martyr had arrived from the southeast. Close relatives of the dead soldier were lamenting and improvising funeral songs $(a \breve{g} l t)$. Just after the ceremonial burying, the father of the dead soldier, an old, bearded man, also began his own funeral songs (which is rare for males to do so). In a melodious voice, the old man uttered sentences like: "Oh, my son! My precious, brave son! Once I wanted to go to Çankırı but had no money. Then I secretly searched your wallet, found a ten-markie-bill ${ }^{2}$ and I took it! How I repent it now!". An officer (a captain in his late thirties) got very touched by that scene. He walked away from the officers, approached the old man, took his hand, kissed it and put it on his forehead in the traditional manner. The crying face of the old man underwent a sudden transformation. A delightful expression of relief settled on the facial traits now. The former compassionate looks of the other villagers were now only admiring the old man, who had been honored by this vivid display of respect by a captain, a status held in high esteem by the Turkish peasants!

It goes without saying that within the military, let alone the higher rank, even the senior private, that is, he who had been longer in the service, attracts an almost awesome respect from his junior fellow soldiers even when age and seniority do not go together, a rare situation in practice ${ }^{3}$.

\section{Two More Case Histories Come as Follows}

Some years ago, in a company in an infantry regiment, one Friday afternoon was dedicated to maintenance (as it was usually the case). The sergeants and the corporals being on duty elsewhere, the interim company commander delegated his authority to the most senior private, Cumali, a very young-looking soldier with a mild facial expression, furthermore. (As a rule thumb, the psychological impact of physical appearance can not be denied in any army). Nevertheless, Cumali did a beautiful job, issuing commands, inspecting the rifles and the equipment one by one, and scolding those who had not done a satisfactory work while cleaning and greasing the barrels of the weapons or warning those with missing equipment, etc. Nobody seemed to argue his statements and behavior. His seniority had obviously equipped him with an uncontestable authority over the rest of the company.

In this same company, one morning a few months later, during the five-kilometer-run, two sub-lieutenants were escorting the soldiers ahead. At a 


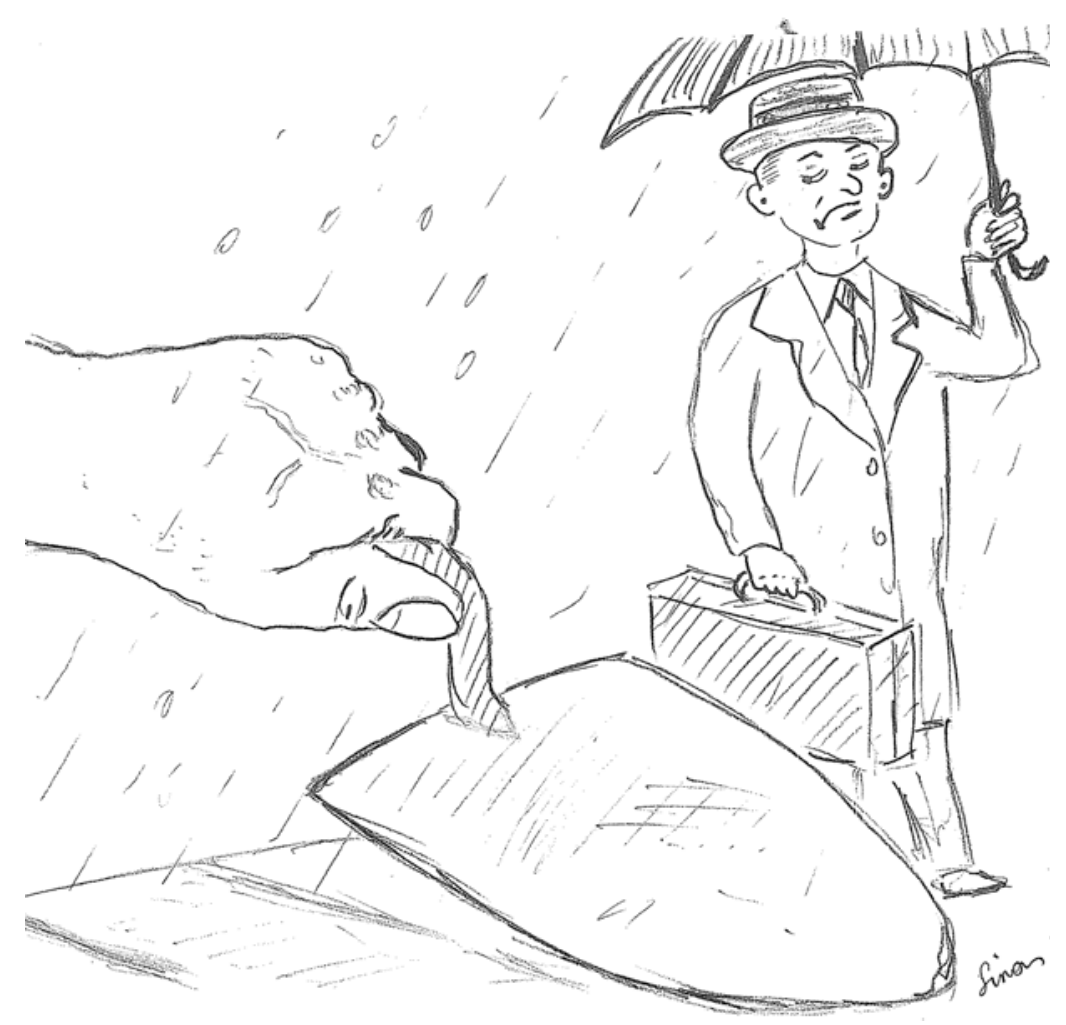

Figure 1. Manual Work May Be Underestimated by Snobbish White-Collars. Source: illustrated by the author.



Figure 2. The Higher the Rank or Position, the Greater Are the Responsibilities as Well as the Worries About Right Decisions and Ethical Issues. Source: illustrated by the author. 
junction, the two sub-lieutenants, after a brisk argument in whispering voices, chose different ways (as a climax of their formerly developed personal conflict). The company, without any hesitation began following the more senior sub-lieutenant (all this in spite of the fact that the less senior sub-lieutenant was generally on better terms with the company, due to his personality). Soldiers there did recognize seniority.

This same factor played the most important role in the remarkable cohesion of the Turkish prisoners of war in Korea.

The Chinese captors segregated leaders and resistors, instituted an informer system, gave special privileges to those who cooperated ("collaborated" would have been a more appropriate word here), and removed all recognition of military rank. As a result, the average American stood alone against his captors, although he was physically in the midst of his fellow prisoners. On the other hand, virtually all the Turkish prisoners captured in the same war successfully resisted attempts by their captors to obtain cooperation (collaboration) by maintaining a high level of discipline and organization, the highest-ranking Turk remaining in charge of the unit and receiving full support from other Turkish prisoners. (Secord and Backman 1974: 135)

\section{AGED PEOPLE ARE CONVENTIONALLY HELD IN RESPECT}

In Turkish society, respect for and even fear of the elderly is like a rule of thumb (Very old people form a different category, though. They remind retirement, mental, and physical debility, etc.). The roots of the idea of obedience to the older people, can be traced from the process of socialization of the Turkish children. They grow up under constant custody/supervision of adults, as different from many Western societies, where a child is granted more personal space (like a whole room of his/her own) and more privacy.

As Bisbee (1951: 85) points out,

Many characteristic attitudes of the Turks become clearer against the background of their childhood and education. The key to child care in Turkish homes is the simple universal motive of protection. No tiny Turk sleeps alone in a dark nursery. Children ordinarily sleep in the room with their parents, or another adult, until the age of eight or 10 , or occasionally even older. By day, adult relatives, servants (this is only true for the rich families), or neighbors take turns watching over them incessantly... Turkish families freely humor (let them do what they wish) children, except when danger is involved. Yet when adult patience cracks, the child is scolded, or otherwise suddenly disciplined.

Throughout the course of growing up, the idea of respect for the adults is inculcated in family circles and schools. Even in adulthood, this social-role-learning goes on.

A foreigner quickly notices the formal courtesy of the Turk's old world manners. Turkish formality forbids a younger man to stand with his hands in his pockets in the presence of an older person, even his own elder brother if there is considerable difference in years. A younger person does not smoke in the presence of an elder unless asked to do so. Nor should anyone, seated on a chair instead of the old-fashioned divan or cushions, cross his legs [here the author is subtly confusing the traditional "bağdaş kurma" sitting style (sitting tailor-fashion/Schneidersitz/lotus position on the ground) with leg-crossing] in the presence of anyone he respects. (Bisbee 1951: 161-162)

Other observers confirm that the elderly have the upper hand in front of the young:

(In Turkey), the most desirable actions strengthen the solidarity of the group. Consultation and cooperative effort rather than individual initiative are the accepted norms of behavior. Primary emphasis is placed upon the family and kin... It is only with some difficulty that the tradition-oriented villager trusts and cooperates with individuals and groups outside the village context, including the national government. In relationships involving nonkinsmen, a person acts much the same as he does toward different kinds of kinsmen; he respects his elders, advises and reprimands his juniors. (Roberts 1970: 168-169)

Anthropologist Pierce, who had already described 
the bride to mother-in-law relationship to us in a picturesque style, has also a lot to say, concerning the seniority relations of men in a Central Anatolian village in 1960s.

Achieved status occurs within the community, but generally speaking one always outranks those in the younger age groups, and has relatively high versus low status only with respect to other members of his own generation... Under the Republic, it is required by law that the Muhtar (village-chief) be an elective office. From 1923 until the mid-fifties, this had little effect, as the villagers simply voted the oldest man back into office at each election. However, in the last election held under Menderes government, the old Muhtar was voted out of office (only) in favor of the next oldest man in the village. It seems likely that as the very large crop of young people go through the public schools, learn more about democratic processes, and mature to become voters, still younger men will be elected to this office until finally it will become truly elective. (Pierce 1964: 84)

That prophecy became reality long ago. Nowadays, age and status are clearly differentiated by almost everyone. But, the traces of the older ways must still be preserved somewhere in the collective memory of the Turkish society.

\section{CONCLUSIONS}

In the Turkish society, dealing with authoritive power is a long-dated preoccupation. Whether imposed from above or intrinsically accepted, it is always there to consider. Respect for the old people is definetely part of tradition. Old age and power are usually correlated. When they do not go together, it is the former which enjoys true feelings of esteem, while the latter may solely find lip-service based on fear.

\section{Notes}

1. In the Turkish slang, such a behavior is called "günah çıkartmak" (confessing his own sin).

2. The Turkish suffix "-clk" or "-cik" is a diminutive grammatical form, implying smallness and affection, so " 10 markçı̆̆ııı" comes to mean "Ton petit 10-mark-note".

3. In an institution, the senior members are those who had entered there before the others did. The idea of seniority usually entails elderliness by age. But it also generally involves a possession of higher legitimate authority. In fact, elderliness and higher authority mostly overlap, though they are distinct concepts per se. In the mind of a young person, nevertheless, authority is mostly associated with age.

\section{References}

Bisbee, E. 1951. The New Turks: Pioneers of the Republic, 1920-1950. Philadelphia: University of Pennsylvania Press.

Dornbusch, S. M. 1956. "Socializing the Cadet.” In Sociology: A Text With Adapted Readings, edited by L. Broom and P. Selznick. New York: Row, Peterson and Company.

Nesin, A. 1996a. "Ölümünün Birinci Yılında Asker Aziz Nesin: Askerin Yüzü Gölgeli Olur” (Former Officer Aziz Nesin at the First Anniversary of His Death: The Face of a Soldier Should Be Shady). Hürriyet (Freedom Newspaper), July 8, p. 13.

— 1996b. "Ölümünün Birinci Yılında Asker Aziz Nesin: Sadece İki Kitap Yasak Değil” (Former Officer Aziz Nesin at the First Anniversary of His Death: Only Two Books Are not Forbidden). Hürriyet (Freedom Newspaper), July 9, p. 12.

Pierce, J. E. 1964. Life in a Turkish Village. New York: Holt, Rinehart \& Winston.

Roberts, T. D. 1970. Area Handbook for the Republic of Turkey. Washington, D.C.: The American University.

Secord, P. F. and C. W. Backman. 1974. Sociol Psychology. New York: McGraw-Hill Book Company.

Tuğrul, M. 1969. Mahmutgazi Köyünde Halk Edebiyatı: Menkıbe, Hikâye, Masal, Fıkra (Anonymous Folk Literature at the Aegean Village of Mahmutgazi: Legends, Stories, Fairy Tales, Funny Anecdotes). İstanbul: Millî Eğitim Basım.

\section{Bio}

Sinan Çaya, Ph.D., Instructor of Social Graduate Elective Courses, Institute of Marine Administration and Sciences, Istanbul University; research fields: rural sociology and peasant studies, military sociology, forensic social sciences, leadership, general education, social history, marine sociology, and marine organizational behavior. 